\title{
Colorectal Sarcoma
}

National Cancer Institute

\section{Source}

National Cancer Institute. Colorectal Sarcoma. NCI Thesaurus. Code C96508.

A malignant soft tissue neoplasm that arises from the colon or rectum. Representative examples include angiosarcoma, Kaposi sarcoma, and leiomyosarcoma. 